\title{
IMPLIKASI AMBIGUITAS TEKS-TEKS AL-QUR'AN DALAM ISTINBÂTH HUKUM ISLAM
}

\author{
Iswah Adriana \\ (Program Studi Pendidikan Bahasa Arab Jurusan Tarbiyah STAIN Pamekasan, \\ jln. Pahlawan, Km.04 Pamekasan, email:Iswah_adri@yahoo.co.id)
}

\begin{abstract}
Abstrak
Bahasa Arab dan al-Qur`an merupakan dua pokok kajian yang tidak bisa terpisahkan. Jika kita mengaji teks-teks Al-Qur'an, mau tidak mau kita akan juga berhadapan dengan bahasa Arab sebagai bahasa al-Qur'an. Bahasa Arab dengan berbagai macam keunikan yang menjadi ciri khasnya merupakan Allah satu faktor kemu'jizatan al-Qur'an. Bentuk-bentuk mufradat yang memiliki variasi makna, uslûb, dan gaya bahasanya yang berbeda dibandingkan dengan seluruh bahasa yang ada di dunia merupakan keistimewaan tersendiri yang dimilikinya. Sebagai kitab suci bagi umat Muslim, tak pelak al-Qur'an selalu menjadi bahan kajian bagi umatnya, dalam mana dilakukan dengan cara mentransfer bahasa Arab ke dalam beragam bahasa lainnya dengan berbagai macam metode. Dalam kaitan ini, seorang penerjemah akan berhadapan dengan berbagai macam keunikan yang dimiliki bahasa Arab, di antaranya banyaknya teks-teks yang 'bersayap'atau dalam kajian semantik disebut dengan teks-teks yang ambigu. Karenanya, pemahaman yang komprehensif tentang konsep ambiguitas merupakan modal utama dalam menerjemah teks-teks al-Qur'an sebagai dasar dalam melakukan istinbâth hukum.
\end{abstract}

\begin{abstract}
Arabic language and the Holy Qur'an have been inseparable mainstreams of study. Once people recite the Qur'an, they automatically make use Arabic as the language of it. Arabic language, with its distinctive uniqueness, is one of the factors of its miracle. The Qur'an contains forms of mufradat (vocabulary) that are varied in meaning, uslûb (manner), and language style. The contents are particularly different from other languages and become its specialty. As the holy book of Moslems, the Qur'an is developed into a source of study by transferring Arabic language to other different languages in various methods. In this context, a translator will face a variety of Arabic uniqueness
\end{abstract}


that are semantically ambiguous. Therefore, a complete comprehension about ambiguity concept will be major tool in translating the texts of Quran as well as a foundation in conducting istinbâth of Islamic law.

\section{Kata-kata Kunci}

ambiguitas, homonim, polisemi, tarjamah tafsiriyah, tarjamah ma'nawiyah, istinbâth

\section{Pendahuluan}

Kesulitan utama dalam melakukan aktifitas penerjemahan antara dua bahasa terletak dalam usaha memadankan kata (lafzh) yang ada pada bahasa sumber ke dalam bahasa sasaran. Namun, hal itu merupakan sesuatu yang tidak mungkin dilakukan, karena setiap kata dalam suatu bahasa belum tentu mempunyai padanannya dalam bahasa yang lain, disebabkan adanya perbedaan budaya dan sosial serta penggunaannya dalam masyarakat. Selain itu, bentuk-bentuk kata yang ambigu juga menjadi salah satu faktor yang cukup menghambat dalam proses penerjemahan. Pengetahuan seseorang akan makna kata atau kalimat akan sangat menentukan kesuksesan sebuah penerjemahan.

Berdasarkan hal tersebut di atas, syarat mutlak yang harus dimiliki seorang penerjemah ketika menerjemah suatu karya ilmiah dari suatu bahasa ke dalam bahasa lainnya adalah pemahaman atas konsep ambiguitas dalam kajian semantik. Terlebih lagi al-Qur'an sebagai karya Allah, Dzât Yang Maha Sempurna. Allah menurunkan wahyu kepada Rasûl-Nya untuk disampaikan dan disebarkan kepada seluruh umatnya, yaitu berupa kitab suci al-Qur`an yang menggunakan bahasa Arab, bahasa yang dipakai oleh Nabi Muhammad saw yang berbangsa Arab. ${ }^{1}$ Karenanya, seseorang yang hendak memahami hukum-hukum atau ajaran Islâm dengan baik, hendaknya ia berusaha mempelajari bahasa Arab. ${ }^{2}$

Bahasa Arab itu sendiri, yang 'dipinjam' oleh Tuhan dalam mentransformasikan ide-ide-Nya dalam al-Qur`an, merupakan bahasa

1Lihat al-Qur`an Surat Yûsûf (12): 2, al-Afqaf (46): 12, Ibrâhîm (14): 4, dan. Fushshilat (41): 44 .

${ }^{2}$ Azhar Arsyad, Bahasa Arab dan Metode Pengajarannya: Beberapa Pokok Pikiran (Yogyakarta: Pustaka Pelajar, 2004), hlm. 7 
yang memiliki ciri khusus yang membedakannya dengan bahasabahasa lainnya, baik dari segi dari segi lafzh, huruf, bunyi, susunan, bentuk, maupun maknanya. ${ }^{3}$ Inilah yang menyebabkan al-Qur`an memiliki kelebihan dari sisi kebahasaan yang memiliki kesulitan tertentu untuk diterjemahkan ke dalam bahasa lain.

\section{Ambiguitas dalam Kajian Semantik}

Ada beberapa pengertian tentang ambiguitas (ketaksaan) yang diberikan oleh para pakar bahasa. Abdul Chaer mendefinisikannya sebagai gejala terjadinya kegandaan makna akibat tafsiran gramatikal yang berbeda 4 . Sedangkan Kridalaksana mengartikannya sebagai sifat konstruksi yang dapat diberi lebih dari satu tafsiran ${ }^{5}$. Contohnya, apabila kita mendengar ujaran, "Anak istri kapten cantik", maka timbul berbagai penafsiran makna, apakah yang dimaksud adalah anaknya istri kapten yang cantik, atau anak dan istri kapten yang cantik. Kesemuanya masih menjadi tanya.

Dalam kajian semantik, ambiguitas atau kekaburan makna bisa disebabkan oleh beberapa hal, di antaranya: ${ }^{6}$ (1) Sifat kata atau kalimat yang bersifat umum (generic). Misalnya, kalau kita berkata buku, maka buku apa yang dimaksud, belum jelas. Demikian pula, kalau kita membaca atau mendengar kalimat "Ali anak Amat sakit", maka belum jelas siapa yang sakit. (2) Kata atau kalimat tidak pernah homogen seratus persen. Maksudnya, kata akan jelas maknanya jika berada di dalam kalimat, dan kalimat akan jelas maknanya jika berada dalam konteks. (3) Batas makna yang dihubungkan dengan bahasa yang berada di luar bahasa tidak jelas. Misalnya, sampai di manakah batas makna kata pandai. (4) Kurang akrabnya kata yang digunakan dengan acuannya. Misalnya, apakah yang dimaksud dengan kata demokrasi dan politik, bagaimanakah orang menerangkan secara jelas makna kata-kata ini?

Ada beberapa cara untuk menghindari kekaburan makna, yaitu: (1) Penambahan unsur segmental, yakni menambah unsur

3Muhammad al-Mubarok, Figh al-Lughah wa Khashâish al-'Arabiyah (Beirut: Dâr al Fikr, 1960), hlm.291

4Abdul Chaer, Linguistik Umum (Jakarta: PT Rineka Cipta, 2003), hlm. 307

${ }^{5}$ Harimurti Kridalaksana, Kamus Linguistik (Jakarta: PT Gramedia Pustaka Utama, 2001), hlm.10

${ }^{6}$ Chaer, Linguistik, hlm. 315. 
berupa kata-kata. Misalnya, kata jagung, belum jelas, tetapi kalau kata jagung tersebut ditambah unsurnya, misalnya menjadi jagung muda, biji jagung, jagung itu, jagung muda yang baru dibeli di pasar, atau jagung muda yang ada di kebun Pak Akib, maka makna kata jagung menjadi lebih jelas. (2) Penambahan unsur suprasegmental, yakni berupa jeda, nada, atau tekanan. Misalnya kalimat Ali anak Amat sakit. Jika dilengkapi dengan jeda yang ditandai oleh tanda baca koma (,), maka kalimat tersebut menjadi jelas. Kalimat Ali, anak, Amat, sakit (bermakna 3 orang yang sakit). Sedangkan kalimat Ali! Anak Amat, sakit (bermakna hanya seorang yang sakit). (3) Pembicara harus mengujarkan kata atau kalimat secara jelas, dan alat bicaranya harus normal. Sedangkan pada pihak pendengar dituntut adanya alat bicara yang normal, perhatian pada objek yang dibicarakan, pemahaman tentang makna kata, banyaknya kata yang dikuasai, dan penguasaan terhadap konteks yang melatarbelakanginya.

Kadang-kadang kita tidak mengerti apa yang diujarkan oleh pembicara karena kita mengantuk, kita tidak mendengarkan dengan penuh perhatian apa yang disampaikan, kita hanya memperhatikan gaya pembicara atau ada gangguan dari luar seperti kebisingan, kegaduhan, ada mobil yang lewat. Kekaburan makna dapat juga terjadi jika kosa kata kita kurang, apalagi kalau kata yang digunakan tidak diketahui maknanya.

Empson mengaklasifikan ambiguitas ke dalam tujuh tipe, yang oleh Ullmann dibagi ke dalam tiga bentuk utama7, yaitu: Pertama, ambiguitas tingkat fonetik. Ambiguitas ini muncul akibat membaurnya bunyi-bunyi bahasa yang diujarkan. Hal ini disebabkan oleh seringkali kata-kata yang membentuk kalimat itu diujarkan secara tepat atau tergesa-gesa, sehingga orang akan ragu-ragu tentang makna kalimat yang dihasilkannya. Contohnya, "Man, tuku wedhus!", menjadi, "mantuku wedhus". Atau kata near, an ear, a near, dan sebagainya. Untuk menghindari ambiguitas seperti ini, maka orang harus bertanya lagi kepada si pembicara.

Kedua, ambiguitas tingkat gramatikal (struktural). Kondisi ini muncul pada satuan kebahasaan yang disebut dengan kalimat atau kelompok kata. Misalnya, kalimat "Anjing makan ayam mati". Ambiguitas pada tingkat ini dibedakan menjadi tiga kemungkinan,

7Mansoer Pateda, Semantik Leksikal (Jakarta: Rineka Cipta, 2001), hlm.202-206 
yaitu: (1) Ia disebabkan oleh peristiwa pembentukan kata secara gramatikal. Misalnya dalam konteks kalimat, karena kata-kata mengandung berbagai makna, apabila kata-kata tersebut berada dalam konteks kalimat. Contohnya, "Apakah Kamu pergi?", siapa yang dimaksud dengan kamu di sini, apakah engkau atau kamu dengan pengertian jamak?; (2) Ia disebabkan oleh frasa yang mirip, yang oleh Ullmann disebut dengan equivocal phrasing, atau amphiboly ${ }^{\text {. Setiap }}$ kata yang membentuk frasa sebenarnya sudah jelas, tetapi kombinasinya dapat ditafsirkan lebih dari satu pengertian. Misalnya, kalimat, "I met a number of old friends and acquaintance" (Saya bertemu dengan sejumlah teman lama dan kenalan). Kata old (lama/tua), jika dihubungkan dengan kata friend dan acquaintance, akan menimbulkan maksud atau penafsiran yang berbeda, apakah teman-teman lama atau kenalan-kenalan lama. Untuk menghindari kemungkinan ini, maka perlu dilihat dari konteks atau unsur suprasegmental yang menyertainya. Seperti frasa orang tua, kalau ditambah menjadi orang yang sudah tua, jelas yang dimaksud adalah orang yang berusia lanjut, tapi kalau diperluas menjadi orang tuaku, maka yang dimaksud adalah ayah dan ibu saya. (3) Ia disebabkan oleh konteks yang berbeda. Untuk menghindari kondisi ini, maka orang harus mengetahui betul pada konteks apa seseorang berbicara.

Ketiga, ambiguitas tingkat leksikal. Karena setiap kata dapat mengandung beberapa makna, maka akan mungkin terjadi sebuah kata mengacu pada sesuatu yang berbeda, sesuai dengan lingkungan pemakaiannya. Misalnya: kata bang, yang bisa mengacu pada kata abang dan bank.

Bentuk seperti contoh di atas disebut dengan polivalensi (polyvalency), yang dibedakan menjadi dua jenis, yaitu: Pertama, polisemi, yakni sebuah kata yang mempunyai dua atau lebih makna, tapi masih berhubungan'. Misalnya, kata mudah mempunyai beberapa makna yang saling berhubungan. Seperti dalam konteks kalimat, "Soal ujian itu sangat mudah" (tidak memerlukan banyak tenaga atau pikiran dalam mengerjakannya, tidak sukar), "Anak kecil mudah

8Istilah ini berasal dari bahasa Yunani, amphi, yang bermakna pada kedua sisi dan ballein yang bermakna kain penutup

9Soekemi Kem, Semantics: A Work Book (Surabaya: UNESA University Press, 2000), hlm. 61 
ketularan penyakit" (lekas sekali), dan "Di kota besar kita mudah tergoda imannya' (tidak teguh imannya).

Dalam kasus polisemi ini, biasanya makna pertama (yang didaftarkan dalam kamus) adalah makna sebenarnya, makna leksikalnya, makna denotatifnya, atau makna konseptualnya. Sedangkan yang lain adalah makna-makna yang dikembangkan berdasarkan salah satu komponen makna yang dimiliki kata atau satuan ujaran itu, sehingga makna-makna pada sebuah kata atau satuan ujaran yang polisemi ini masih berkaitan satu sama lain.

Kedua, homonim, yakni dua buah kata atau satuan ujaran yang bentuknya 'kebetulan' sama. Maknanya tentu saja berbeda, karena masing-masing merupakan kata atau bentuk ujaran yang berlainan. Misalnya, kata barang, mempunyai makna yang berbeda dan tidak berhubungan. Seperti dalam kalimat, "Banyak barang diturunkan di pelabuhan' (benda yang diperdagangkan) dengan kalimat, "Berilah saya barang 1000 rupiah' (sejumlah, sebanyak). Homonim ini dibedakan menjadi dua ${ }^{10}$, yaitu: (1) homofon, yaitu kesamaan bunyi antara dua satuan ujaran, tanpa memperhatikan ejaannya, apakah ejaannya sama atau berbeda. Contohnya, bank dan bang, demikian juga sangsi dan sanksi. (2) homograf, yaitu bentuk ujaran yang sama ortografinya (ejaannya), tetapi ucapan dan maknanya tidak sama. Contohnya, kata teras, yang bermakna inti dan serambi rumah.

Ambiguitas bisa terjadi pada dua kondisi, yaitu: ${ }^{11}$ Pertama, terjadi pada bahasa tulis. Hal ini biasanya disebabkan oleh dua faktor: (1) Diakibatkan oleh tafsiran gramatikal yang berbeda, karena pada bahasa tulis unsur suprasegmentalnya tidak dapat digambarkan secara akurat. Misalnya, kalimat, "Buku sejarah baru", bisa memuat dua penafsiran, yaitu bukunya yang baru atau sejarahnya yang baru. (1) Karena masalah homonim, sedangkan konteksnya tidak jelas. Misalnya, kalimat, "Mereka bertemu paus", memiliki dua penafsiran, yaitu bertemu paus (nama hewan mamalia air) atau bertemu paus (nama pemimpin agama katolik). Dari sini dapat disimpulkan, bahwa

10David Crystal, A Dictionary of Linguistics and Phonetics (Basil: Blackwell, 1997), hlm.185

11Wallace L. Chafe, Meaning and the Structure of Language (Chicago and London: The University of Chicago Press, 1970), hlm. 125 
ambiguitas itu hanya terjadi dalam bahasa tulis, akibat dari perbedaan gramatikal karena ketiadaan unsur intonasi.

Kedua, terjadi pada bahasa lisan. Ini terjadi karena ketidakcermatan dalam menyusun konstruksi beranaforis. Misalnya, kalimat, "Ujang dan Nanang bersahabat karib. Dia sangat mencintai istrinya". Dua kalimat ini menimbulkan pertanyaan, Siapa yang mencintai, istri siapa?

\section{Ambiguitas sebagai Ciri Khas dan Keunikan Bahasa Arab sebagai Bahasa al-Qur'an}

Para ulamâ' sepakat mengenai kelebihan dan keunikan yang dimiliki bahasa Arab sebagai bahasa al-Qur`an, nota bene tidak dimiliki oleh bahasa-bahasa lainnya. Bahasa Arab merupakan bahasa yang terluas dan terkaya kosa katanya, kandungannya, deskripsinya, dan pemaparannya yang sangat detail.12 Bahkan menurut beberapa pakar bahasa Arab, ditemukan sekitar 25 juta kosa kata bahasa Arab dan banyaknya kata-kata ambigu (bersayap).

Berdasarkan hal tersebut, kosa kata dalam bahasa Arab ditinjau dari kajian semantik dan berdasarkan maknanya dibagi ke dalam tiga bagian ${ }^{13}$, yaitu: Pertama, monosemy, yakni satu kata yang hanya mempunyai satu makna. Dalam hal ini tidak ada persoalan.

Kedua, synonyme (مترادف), yakni adanya beberapa kata yang mempunyai makna yang sama. Contohnya, dalam kamus al-Muhith, sinonim kata عسل yang berarti madu, terdapat 80 kata. Sedangkan sinonim kata yang berarti pedang terdapat sekitar 1000 kata. De' Hammaer mengatakan kata yang menunjuk kepada unta dan keadaannya terdapat $5644 \mathrm{kata}^{14}$. Namun demikian, tidak semua sinonim-sinonim tadi mempunyai arti yang sama persis. Hal itu bisa dilihat pada kata جلس dan قعد yang sama-sama memiliki arti duduk, tetapi penggunaannya berbeda jika diterapkan dalam bentuk

12Nayif Mahmûd Ma'ruf, Khashâish Arabiyah wa Tharâiq Tadrisihâ (Beirut: Dâr al Nafâis, 1985), hlm. $\overline{89}$

13Farid 'Awdh Khaydar, 'Ilm al-Dilâlah: Dirâsah Nadhriyyah wa Tathbâqiyyah (Kairo: Maktabah al-Nahdhah al-Mishriyyah, 1999), hlm. 119

14‘Alî Abd al-Wahid Wâfí, Figh al-Lughah (Mesir: Lajnah al-Bayân al-Arabi, 1957), hlm. 57 
perintah.15 إجلس digunakan untuk memerintahkan seseorang yang sedang berbaring agar ia duduk, sedangkan أقعد أق digunakan jika lawan bicara kita berdiri.

Untuk lebih jelasnya, berikut ini akan diketengahkan contoh dalam al-Qur`an Surat al-A'râf: 172 yang berbunyi, ألست بربكم * قالوا بلى Menurut Ibnu Abbâs, seandainya kata بنعم diganti, maka yang menjawab demikian akan kafir, karena lafazh نع digunakan untuk menjawab suatu pertanyaan yang benar, baik pertanyaan itu redaksinya positif maupun negatif. Dengan demikian, apabila kalimat tadi dijawab dengan نع artinya menjadi, "Benar, engkau bukan Tuhanku". Tetapi kalau dijawab dengan ربلى berarti membenarkan jawaban hanya dalam bentuk positif, sehingga negasinya harus dibuang dulu.

Ketiga, homonyme (مشترك اللفظى), yakni adanya satu kata yang sama dan mempunyai beberapa makna, termasuk di dalamnya الأضداد (antonyme). Bahasa Arab memiliki keistimewaan dengan gejala berpindah-pindahnya maknakata sesuai dengan konteks zaman, tempat, dan kondisi yang berlaku. Misalnya, kata ضرب bisa berarti memukul, menggigit, membakar, menembak, membacok, dan sebagainya. Pemilihan makna kata dalam menerjemahkan menuntut kecermatan dan ketelitian yang ekstra, agar penerjemahan sesuai dengan orientasi yang diinginkan. ${ }^{16}$ Bahkan satu huruf tidak jarang mempunyai lebih dari satu arti, seperti pada huruf wawu (و). Huruf ini dibagi ke dalam dua bagian: Pertama, yang berfungsi: (a). واو القسم (و) (sumpah), و و الله , yang mengakibatkan majrur; (b). واو المعية (bersama), yang mengakibatkan manshûb. Kedua, yang tidak berfungsi, di mana dalam hal ini terdapat bberapa makna, di antaranya adalah isti'naf, yakni kalimat yang berada sesudah huruf tersebut tidak mempunyai hubungan dengan kalimat sebelumnya, baik dari segi makna maupun

${ }^{15}$ Quraish Shihab, Mukjizat Al-Qur'an: Ditinjau dari Aspek Kebahasaan, Isyarat Ilmiah, dan Pemberitaan Ghaib ( Bandung: Mizan, 2001), hlm.96

16Radliyah Zaenuddin, et al., Metodologi dan Strategi Alternatif Pembelajaran Bahasa Arab (Yogyakarta: Pustaka Rihlah Group, 2005), hlm.17 
konjugasi. ${ }^{17}$ Kesalahpahaman yang berkaitan dengan hal ini seringkali mengantarkan penerjemah untuk menerjemahkannya dengan 'dan', padahal terjemahan yang demikian ini tidak diperlukan.

\section{Implikasi Ambiguitas Teks-teks al-Qur`an dalam Istinbâth Hukum}

Perbedaan makna dalam suatu kosa kata akan memberikan implikasi dalam menetapkan (istinbâth) hukum ${ }^{18}$. Hal ini dibuktikan oleh teks-teks yang ambigu berikut ini:

1. Kata قروء dalam surat al-Baqarah (2): 228, yang berbunyi:

$$
\text { والمطلقات يتربّ بـ بأنفسهّن ثلاثة قروء }
$$

"Wanita-wanita yang ditalak hendaklah menahan diri (menunggu) tiga kali quru'". 19

Makna qurû' di atas bisa diartikan 'suci' (menurut Imâm Syâfi'î) atau 'haidh' (menurut Imâm Abû Hanîfah). Kata قرو yang mempunyai dua makna yang berbeda dan saling berlawanan tersebut dalam konsep ambiguitas disebut dengan الأضداد yang termasuk bagian dari homonim (مشترك اللفظى).

2. Kata لمس dalam surat al-Mầidah (5): 6, yang berbunyi:

$$
\text { وإن كتم مرضى أو على سفر أو جاء احد من الغائط أو لمستم النساء... }
$$

“...dan jika kamu sakit atau dalam perjalanan atau kembali dari tempat buang air (kakus) atau menyentuh perempuan,..."20

Makna لمس di atas mempunyai dua pengertian, yaitu 'menyentuh' (menurut al-Syâfi'î) dan 'bersetubuh' (menurut Abû Hanîfah). Kata لمس yang bermakna 'menyentuh' dan 'bersetubuh' di atas dalam konsep ambiguitas termasuk ke bagian ambiguitas leksikal yaitu polisemi, karena masih ada hubungan antara kedua maknanya.

3. Kata ضرب dalam surat al-Nisâ' (4): 34, yang berbunyi:

\footnotetext{
17Badr al-Dîn Muhammad bin 'Abd Allâh al-Zarkâzî, al-Burhân fî̀ 'Ulûm al-Qur'ân (Beirut: Dâr al-Ma' rifat li al-Thibâ'ah wa al-Nasyr, 1992), hlm. 47.

18Zaitunah Subhan, Rekonstruksi Pemahaman Jender dalam Islam (Jakarta: el-Kahfi, 2002), hlm.xv

${ }^{19}$ Departemen Agama RI., Al-Qur'aan dan Terjemahnya (Jakarta: PT. Bumi Restu, 1976/1977), hlm. 55.

20 Ibid., hlm. 158.
} 


$$
\text { و اللاتى تخافون نشوزهن فعظوهن واهجروهن في المضاجع واضربوهن ... }
$$

"Wanita-wanita yang kamu khawatirkan nusyuznya maka nasihatilah mereka dan pisahkan dari tempat tidur dan pukullah mereka". ${ }^{21}$

Kata ضرب di atas tidak hanya memiliki satu makna, yaitu 'memukul', tetapi ia juga bermakna 'menempuh perjalanan',22 'membuat', 23 'menutupi', 24 dan 'ditimpakan/diliputi', ${ }^{25}$, dan sebagainya. Dalam bahasa Arab yang berkembang dewasa ini, lafdz ضرب juga bermakna 'bertindak tegas', sehingga Muhammad Sahrûr, sebagaimana dikutip Husayn Muhammad, mamaknai lafzh tersebut sebagai 'bertindak tegas terhadap mereka'. ${ }^{26}$ Jadi, meskipun bentuk kata ضرب di atas bentuknya amar, akan tetapi bukan berarti laki-laki diperintahkan untuk memukul istrinya yang nusyûz. Makna ضرب di atas lebih tepat bermakna 'bertindak tegas'. Namun demikian, seandainya makna tersebut diartikan 'memukul', maka 'memukul' di sini bukanlah makna yang sebenarnya, tetapi merupakan makna konotatif. Dalam konteks ambiguitas kata ضرب termasuk bagian dari homonim, karena masing-masing maknanya tidak mempunyai hubungan.

4. Kata لباس dalam surat al-Baqarah (2): 187, yang berbunyi:

$$
\text { هن لباس لكم و انتم لباس لمن }
$$

"Mereka itu adalah pakaian bagimu, dan kamu pun adalah pakaian bagi mereka" 27

Makna 'pakaian' pada kata لباس di atas bukanlah menunjukkan makna secara denotatif (makna sebenarnya), tapi yang dimaksud dengan pakaian di sana adalah simbol dari kebutuhan dasar antara laki-laki dan perempuan. Dengan kata lain, ia menunjukkan hubungan yang setara untuk saling melengkapi, saling membutuhkan, dan saling melindungi sebagai

21 Ibid., hlm. 123.

22 Al-Qur`an Surat al-Nisâ' (4): 101.

23 Ibid., al-Tahrî̀m (66):10, Yâsin (36): 13, al-Baqarah (2): 26, dan Ibrâhîm (14): 25

24 Ibid., al-Nûr (24): 31

25 Ibid., al-Baqarah (2): 61.

${ }^{26}$ Husein Muhammad, Islam Agama Ramah Perempuan: Pembelaan Kiai Pesantren (Yogyakarta: LKiS, 2004), hlm.253-254

27 Departemen Agama RI., Al-Qur'an, hlm. 45. 
partner dalam menyalurkan hasrat seksualnya. ${ }^{28}$ Dengan demikian, kata لباس yang mempunyai makna 'pakaian' dan 'partner dalam berhubungan seks' termasuk ke dalam polisemi, karena masih ada keterkaitan makna di antara keduanya.

5. Kata حرثdalam surat al-Baqarah (2): 223, yang berbunyi:

$$
\text { نساؤكم حرث لكم فأتوا حرثكم ان شئتم }
$$

"Istri-istrimu adalah tanah tempat kamu bercocok tanam (ladang), maka datangilah ladangmu itu bagaimana saja kamu kehendaki". ${ }^{29}$

Makna 'ladang' pada kata حرث di atas bukanlah berarti bahwa perempuan itu sama dengan ladang, tetapi yang dimaksud 'ladang' di sini adalah فرج (vagina), bukan anus (dubur) atau lubang yang lain. Jadi ayat ini memberikan kebebasan dalam melakukan hubungan seksual asalkan masih berada pada vagina, dan untuk menentukan 'bagaimana' kebebasan cara ini diterapkan diperlukan musyawarah antara suami dan istri terlebih dahulu. Ayat ini sekaligus menunjukkan bahwa hubungan seksual sesungguhnya bukan semata-mata untuk kepentingan reproduksi melainkan juga untuk kepentingan rekreasi.30 Dalam konsep ambiguitas hal ini termasuk dalam bentuk polisemi, di mana antara makna 'ladang' dan 'vagina' mempunyai hubungan, yakni sama-sama bisa diartikan sebagai 'tempat untuk menanam benih', walaupun 'benih' yang dimaksud berbeda.

\section{Model Penerjemahan Teks-teks Ambigu dalam al-Qur’an}

Secara lughawî, terjamah berarti pemindahan atau pengalihan. ${ }^{31}$ Sedangkan menurut istilah, terjemah bermakna usaha memindahkan pesan dari teks berbahasa Arab (teks sumber) dengan padanannya ke dalam bahasa Indonesia (bahasa sasaran). ${ }^{32}$ Sedangkan Newmark

28 Marzuki Wahid, “Mendaulatkan Seksualitas Perempuan”, Swara Rahima, No. 5 Th. II (Juli 2002), hlm. 37

${ }^{29}$ Departemen Agama RI., al-Qur'an, hlm. 54.

30 Ibid., hlm. 36

31Sayyid Muhammad Alwi al-Maliki, Keistimewaan-Keistimewaan Al-Qur'an (Yogyakarta: Mitra Pusaka, 2001), hlm. 150

32Ibnu Burdah, Menjadi Penerjemah: Metode dan Wawasan Menerjemah Teks Arab (Yogyakarta: Tiara Wacana, 2004), hlm. 9-10 
mengatakan bahwa terjemahan adalah proses memadankan konsep kata, frase, dan kalimat yang terdapat pada teks bahasa yang satu ke dalam bahasa yang lain. ${ }^{33}$ Bahkan terjamah ini didefinisikan juga sebagai proses memadankan ungkapan atau kalimat dalam satu bahasa dengan genre yang berbeda, seperti dari bentuk syi'ir ke dalam bentuk prosa. 34

Pendefinisian terjemah seperti tersebut di atas dimaksudkan sebagai upaya untuk memindahkan pesan seutuh dan semaksimal mungkin ke dalam bahasa sasaran. Namun dengan adanya definisi terjemah yang hanya memfokuskan pada 'pengalihan pesan' memberikan peluang kepada penerjemah untuk berbuat 'semenamena' dan sebebas mungkin dalam mentransfer suatu pesan dari bahasa sumber ke bahasa sasaran tanpa mengindahkan aspek-aspek lain di luar pesan, seperti padanan-padanan linguistik, struktur, pengungkapan secara denotatif-konotatif atau hal-hal lain di luar teks. Jadi, pendefinisian terjemah seperti itu memberi peluang besar bagi masuknya interpretasi-interpretasi lain (seperti meringkas, menyadur ataupun menafsirkan).

Sedangkan definisi yang hanya menekankan pada unsur padanan, menuntut penerjemah untuk menghasilkan terjemahan yang berimbang antara teks sumber dengan hasil terjemahan, baik dari sisi proporsi linguistik maupun pesannya, sehingga cenderung 'mengikat' dan 'membatasi' kebebasan dan 'kesewenang-wenangannya' dalam menterjemah ${ }^{35}$.

Dengan membandingkan kedua definisi terjemah yang beda dalam penekanannya tersebut di atas, perlu kiranya membangun suatu definisi terjemah yang tidak hanya menekankan pada satu unsur saja, baik pesan maupun padanan, tapi mencakup keduanya, yakni kombinasi antara kebebasan menyampaikan pesan dan ketepatan proporsi terjemahan dengan teks sumbernya.

Dari definisi tersebut di atas, hasil karya terjemahan sering dikelompokkan pada dua kategori yang saling berlawanan, yaitu: Pertama, tarjamah harfiyah (literer), yakni mengganti lafzh asal dengan

\footnotetext{
${ }^{33}$ Mansoer Pateda, Linguistik Terapan (Flores: Nusa Indah, 1991), hlm. 131

${ }^{34}$ Ahmad Mukhtar 'Umar, 'Ilm al-Dilâlah (Kuwait: Maktabah Dâr al-'Arubah li alNasyr wa al-Tauzi'), hlm. 222-223

35 Burdah, Menjadi Penerjemah, hlm. 15
} 
lafzh bahasa lain yang mempunyai arti sama, tanpa mendudukkan kesesuaian makna yang pokok. ${ }^{36}$ Model terjemahan ini sangat 'setia' terhadap teks sumber. Penerjemah berusaha memaksakan aturanaturan yang ada dalam tata bahasa Arab ke dalam bahasa Indonesia, padahal kedua bahasa tersebut memiliki tata bahasa yang berbeda. ${ }^{37}$ Akibatnya, hasil terjemahannya sangat kaku, yakni berbentuk bahasa Indonesia yang 'berbau' Arab, sehingga kelihatan sangat aneh dan membingungkan ketika dibaca oleh penutur bahasa Indonesia.

Kedua, tarjamah bi al-tasharruf atau ma'nawiyah tafsiriyah, yaitu menerangkan dan menjelaskan makna suatu kalimat dengan bahasa lain tanpa terbatasi oleh susunan dan penjagaan gaya bahasa asal. ${ }^{38}$ Artinya, terjemahan ini tidak mempedulikan aturan tata bahasa yang ada dalam bahasa sumber, tetapi orientasinya adalah pemindahan makna. ${ }^{39}$ Metode penerjemahan al-talkhish wa al-ikhtiyâr juga merupakan bagian dari kategori ini, karena model terjemahan ini berusaha memahami suatu teks dan meringkas makna yang utama. ${ }^{40}$

Meskipun terdapat dua kategori yang ada pada hasil terjemahan seperti di atas, namun pada dasarnya tidak ada hasil terjemahan yang benar-benar murni harfiyah atau tafsiriyah. Justru yang sering dijumpai dalam kenyataannya adalah terjemahan yang berada di antara keduanya, yang disebut dengan tarjamah semi-harfiyah atau tarjamah semi-tafsiriyah (شبة الحرفية وبة التفسيرية ). Tarjamah semi-harfiyah biasanya cenderung literer dan terjadi pada dua bahasa yang mempunyai kekerabatan yang sangat dekat yang digambarkan oleh kemiripan tata bahasanya. Sedangkan tarjamah semi-tafsiriyah cenderung lebih bebas dan terjadi pada dua bahasa yang memiliki perbedaan tata bahasa yang cukup signifikan, seperti terjemahan dari bahasa Arab ke dalam bahasa Indonesia.

Memperhatikan model-model penerjemahan di atas adalah sahsah saja dilakukan oleh seorang penerjemah kalau itu terjadi pada penerjemahan hasil karya manusia. Persoalannya adalah bagaimana kalau hal itu dilakukan terhadap kalam Allah, yaitu al-Qur`an? Allah

\footnotetext{
${ }^{36}$ Al-Maliki, Keistimewaan-Keistimewaan Al-Qur'an, hlm. 150

37 Burdah, Menjadi Penerjemah, hlm. 16

38 Ibid.

${ }^{39}$ Ibid.

${ }^{40} \mathrm{Abd}$ al-Ghaffar Hamîd Hilâl, al-'Arabiyyah: Khashâishuhâ wa Simmatuha (Kairo: Khuququ al-Thaba' wa al-Natsr, 1995), hlm. 510.
} 
melarang orang-orang membelokkan terjemahan al-Qur`an. Dia berwasiat agar menjaga dan memelihara Kitab-Nya dari perubahan dan penggantian. Bahkan, Dia mencela orang yang melakukan pembelokan. ${ }^{41}$ Orang-orang yang menerjemahkan al-Qur`an secara harfiyah berarti merubah kemukjizatan, mengganti maksud, dan membelokkan arahnya. Tindakan tersebut berarti meruntuhkan kearaban al-Qur’an, mengurai ikatan Islâm yang bersifat Arab, dan memudarkan sifat kesatuannya. ${ }^{42}$

Terjemahan al-Qur'an yang baik adalah terjemah tafsiriyahma'nawiyah terhadap hukum-hukum yang ada dalam al-Qur'an, karena dengannya berarti tetap menjaga kemuliaan al-Qur`an dan sesuai penetapan Sunnah. Menerjemah al-Qur'an secara tafsiriyahma'nawiyah dapat dilakukan dengan syarat sebelumnya dilakukan pemeriksaan sahabat, tâbi'în, dan ulama Ahl al-Sunnah Nabi. Terjemahan seperti ini akan lebih sempurna apabila diberikan keterangan penetapan hukum al-Qur`an, sehingga jelas bagi orangorang non Arab untuk memahaminya. Selain bersumber dari Nabi, penafsiran dapat dilakukan melalui istinbâth. Kebolehan ini dipraktikkan oleh para sahabat yang berbeda dalam menafsirkan alQur'an yang mereka baca. Perbedaan penafsiran tersebut bukan bersumber dari sabda Nabi yang mereka dengar, namun merupakan hasil istinbath mereka.

Perlu dicatat bahwa faktor-faktor yang menjadikan penerjemahan al-Qur'an merupakan suatu upaya yang sia-sia adalah adanya keunikan bahasa Arab yang dalam hal ini ditunjukkan dengan banyaknya kosa kata (mufradat) yang ambigu. Karenanya, penerjemahan yang diikuti dengan penafsiran merupakan langkah yang tepat dalam memahami ayat-ayat al-Qur'an yang ambigu, terutama yang berkaitan dengan masalah istinbâth hukum.

\section{Penutup}

Dari ulasan di atas, jelas terlihat bahwa ayat-ayat al-Qur`an tersusun dalam kosa kata bahasa Arab. Banyak sekali keistimewaan dan kelebihan-kelebihan yang dimilki oleh bahasa Arab dibandingkan bahasa-bahasa lain yang ada di dunia ini, yang di antaranya adalah

${ }^{41}$ Lihat al-Qur'ân Surat al-Baqarah (2): 181 dan Alî Imrân (3): 78.

42 Ibid, hlm. 157 
banyaknya kosa kata yang ambigu. Pemahaman atas ambiguitas inilah yang semestinya difahami oleh seorang penerjemah, sehingga ia akan melakukan model penerjemahan al-Qur'an secara tafshiriyahma'nawiyah.

Problematika teologis dalam penafsiran al-Qur`an tentang teks-teks yang ambigu bisa membawa implikasi terhadap istinbâth hukum. Sehingga kalau al-Qur'an diterjemahkan ke dalam bahasa lain, tanpa diikuti oleh penafsiran terhadap teks yang sangat rawan terhadap penafsiran, yakni teks-teks yang ambigu, dengan teliti dan cermat, tidak mustahil akan bisa merubah cara pandang umat Muslim terhadap hukum yang ada.

\section{Daftar Pustaka}

'Umar, Aḥmad Mukhtar. 'Ilm al-Dilâlâh. Kuwait: Maktabah Dâr al'Arubah li al-Nasyr wa al-Tauzi'

Arsyad, Azhar. Bahasa Arab dan Metode Pengajarannya: Beberapa Pokok Pikiran. Yogyakarta: Pustaka Pelajar, 2004

Burdah, Ibnu. Menjadi Penerjemah: Metode dan Wawasan Menerjemah Teks Arab. Yogyakarta: Tiara Wacana, 2004

Chaer, Abdul. Linguistik Umum. Jakarta: PT Rineka Cipta, 2003

Chafe, Wallace L. Meaning and the Structure of Language. Chicago and London: The University of Chicago Press, 1970

Crystal, David. A Dictionary of Linguistics and Phonetics. Basil: Blackwell, 1997

Departemen Agama RI., Al-Qur'aan dan Terjemahnya. Jakarta: PT. Bumi Restu, 1976/1977

Hilâl, Abd al-Ghaffar Hamîd. al-'Arabiyyah: Khashâishuhâ wa Simmatuhâ. Kairo: Khuququ al-Thaba' wa al-Natsr, 1995

Kem, Soekemi. Semantics: A Work Book. Surabaya: UNESA University Press, 2000

Khaydar, Farid 'Awdh. 'Ilm al-Dilâlah: Dirâsah Nadhriyyah wa Tathbâqiyya.h(Kairo: Maktabah al-Nahdhah al-Mishriyyah, 1999

Kridalaksana, Harimurti. Kamus Linguistik (Jakarta: PT Gramedia Pustaka Utama, 2001)

Maliki, Sayyid Muhammad Alwi al-. Keistimewaan-Keistimewaan AlQur'an. Yogyakarta: Mitra Pusaka, 2001

Ma'ruf, Nayif Mahmûd. Khashâish Arabiyah wa Tharâiq Tadrisihâ. Beirut: Dâr al Nafâis, 1985 
Mubarok, Muhammad al-. Figh al-Lughah wa Khashâish al-'Arabiyah (Beirut: Dâr al Fikr, 1960)

Muhammad, Husein. Islam Agama Ramah Perempuan: Pembelaan Kiai Pesantren. Yogyakarta: LkiS, 2004

Pateda, Mansoer. Linguistik Terapan. Flores: Nusa Indah, 1991 Semantik Leksikal. Jakarta: Rineka Cipta, 2001

Shihab, Quraish. Mukjizat Alqur'an: Ditinjau dari Aspek Kebahasaan, Isyarat Ilmiah, dan Pemberitaan Gaib. Bandung: Mizan, 2001

Subhan, Zaitunah. Rekonstruksi Pemahaman Jender Dalam Islam. Jakarta: el-Kahfi, 2002

Wâfî, 'Alî Abd al-Wahid. Figh al- Lughah. Mesir: Lajnah al-Bayân alArabi, 1957

Wahid, Marzuki. "Mendaulatkan Seksualitas Perempuan", Swara Rahima, N0. 5 Th. II (Juli 2002)

Zaenuddin, Radliyah et.al., Metodologi dan Strategi Alternatif Pembelajaran Bahasa Arab. Yogyakarta: Pustaka Rihlah Group, 2005

Zarkazî, Badr al-Dîn Muhammad bin 'Abd Allâh al-, al-Burhân fì 'Ulûm al-Qur'ân. Beirut: Dâr al-Ma'rifat li al-Thibâ'ah wa alNasyr, 1992 